\title{
Comparative Study of Soil Tillage Practices Effects on Hydraulic Conductivity and Bulk Density of a Sandy Loam Soil in Tunisia
}

\author{
Roua Amami ${ }^{1 *}$, Khaled Ibrahimi ${ }^{1}$, Khaoula Abrougui ${ }^{1}$, Amira Hmila ${ }^{1}$, Sayed Chehaibi ${ }^{1}$
}

${ }^{1}$ Higher Institute of Agricultural Sciences, Sousse University, 4042 Chott Meriem, TUNISIA

*Corresponding Author: roua.amami1991@gmail.com

Citation: Amami, R., Ibrahimi, K., Abrougui, K., Hmila, A., \& Chehaibi, S. (2019). Comparative Study of Soil Tillage Practices Effects on Hydraulic Conductivity and Bulk Density of a Sandy Loam Soil in Tunisia. Aquademia, 3(1), ep19013. https://doi.org/10.21601/aquademia/9567

\section{ARTICLE INFO}

Received: 26 Jan. 2019

Accepted: 30 Jun. 2019

\begin{abstract}
The aim of this study was to investigate the effects of different tillage practices on bulk density, and the hydraulic properties of a sandy loam soil of eastern Tunisia. A replicated randomized complete block design with treatments consisting of (i) no-tillage (NT), (ii) tillage with moldboard plow at three level depths $(\mathrm{SM}=15 \mathrm{~cm}$, $\mathrm{MM}=20 \mathrm{~cm}$ and $\mathrm{DM}=25 \mathrm{~cm}$ ), (iii) and tillage with disc plow at three level depths $(\mathrm{SD}=15 \mathrm{~cm}, \mathrm{MD}=20 \mathrm{~cm}$ and $\mathrm{DD}=25 \mathrm{~cm}$ ) practices established at the Higher Institute of Agricultural Sciences of Sousse; Tunisia was used for the study. The soil bulk density and saturated hydraulic conductivity were determined for each of the treatments. The bulk density (BD) was determined at the depths of 5,15 and $25 \mathrm{~cm}$ while the saturated hydraulic conductivity was determined on the surface $(0-10 \mathrm{~cm})$ soil. Experimental results showed that all the tillage practices were significantly different in their effects on soil density and was in the descending order of NT>SD> $\mathrm{MD}>\mathrm{DD}>\mathrm{SM}>\mathrm{MM}>\mathrm{DM}$. The soil bulk density decreased with the degree of soil manipulation during tillage practices, with NT having the highest $\left(1.76 ; 1.86\right.$ and $\left.1.81 \mathrm{~g} \mathrm{~cm}^{-3}\right)$ and DD having the least $(1.60 ; 1.56$ and $1.59 \mathrm{~g}$ $\mathrm{cm}^{-3}$ ) respectively for 5,15 and $25 \mathrm{~cm}$ depths. The greater mean value of Ksat was found in DD while the lowest was found in NT with 36\% reduction than DD. The research concluded that the best Tillage Practices to be adopted in terms of improvement in physical and hydraulic properties is Shallow tillage practice.
\end{abstract}

Keywords: tillage, disc plow, moldboard plow, bulk density, hydraulic conductivity, beerkan test, Best Method

\section{INTRODUCTION}

Over the decades, reduction of tillage requirements has been the principal motivating force in agricultural mechanization (Osunbitan et al., 2005). Tillage is the most widely researched management practice affecting hydraulic conductivity and physical properties of the soil (Strudley et al., 2008). Many researchers examined the influence of tillage practices on soil bulk densities. According to Hammel et al. (1989) bulk density in the top $300 \mathrm{~mm}$ of silt loam soil were higher with zero tillage than with minimum or conventional tillage practices. Hoffman (1990) also observed that bulk densities of zero tillage and minimum tillage increased from the surface of the soil to a depth of $150 \mathrm{~mm}$. Previous studies show that high $\mathrm{BD}$, strong soil crust and low total porosity have a negative influence infiltration rates (Bhattacharyya et al., 2006; Gicheru et al., 2004). Bulk density is inversely related to total porosity (Carter \& Ball,1993), which gives us an idea of the porous space left in the soil for air and water movement. Than when tillage is reduced, soil porosity tends to increase (Voorhees \& Linstrom, 1984), and often, surface sealing occurs, reducing the infiltration rate (Lindstrom \& Onstad, 1984).

Previous investigations Messing et Jarvis (1993) and Nicolas B, 2010, have found that $\mathrm{K}(\mathrm{h})$ showed a large intraannual variability, decreasing shortly after tillage under tilled treatments, followed by an increase in the spring and a decrease in the summer for the three tillage treatments.

Kamemickova et al. (2012) mentioned that the tillage practices of the top layer of the soil plays a key role in the changes of the hydro-physical properties, mainly saturated hydraulic conductivity of the upper layer, soil perforation through tillage enhances soil water catchment and increases the infiltration of water into the soil surface, raising the hydraulic conductivity sorptivity values (Abrisqueta et al., 2006).

There are no recorded experiences on the influence of different tillage systems on the soil bulk densities and hydraulic conductivity in semi arid region of eastern Tunisia. On this background, the objectives of this study were to evaluate the effects of tillage implements, on soil Bulk density and hydraulic conductivity in sandy loam soil in eastern Tunisia. 
Table 1. Coordinates of the experimental site and Soil properties in the horizon $(0 \pm 30 \mathrm{~cm})$ of the experimental site before the commencement of the tillage treatments (clay, silt and sand content (US Department of Agriculture classification system)

\begin{tabular}{lc}
\hline Variable & Value \\
\hline Coordinates & $35^{\circ} 54^{\prime} 5.82$ N $-10^{\circ} 33^{\prime} 46.84 ” \mathrm{E}$ \\
\hline Clay $(\%)$ & 11.12 \\
\hline Silt $(\%)$ & 6.28 \\
\hline Sand $(\%)$ & 77.96 \\
\hline Textural triangle & Sandy-loam \\
\hline Bulk density $\rho b\left(\mathrm{gcm}^{-3}\right)$ & 1.93 \\
\hline Particle density $\left(\mathrm{gcm}^{-3}\right)$ & 2.49 \\
\hline Soil-water content $\theta 0\left(\mathrm{~cm}^{3} \mathrm{~cm}^{-3}\right)$ & $10.53 \%$ \\
\hline
\end{tabular}

\section{MATERIALS AND METHOD}

\section{Location and Climate}

The experimental site was located in Sousse region in the Center East of Tunisia and belongs to the Higher Institute of Agronomic Science of Chott Mariem (35 $54^{\prime} 5.82$ ”N$\left.10^{\circ} 33^{\prime} 46.84^{\prime \prime} \mathrm{E}\right)$. The climate of the area is semi-arid Mediterranean; with a mean annual air temperature vary from 16 to $19^{\circ} \mathrm{C}$ and a rainfall close to $400 \mathrm{~mm}$. A brief description of the soil properties at the start of the experiment is shown in Table 1.

The area, is rectangular and fairly flat and extends for approximately 0.126 ha $\left(63 \times 20 \mathrm{~m}^{2}\right)$. It was divided into 21 subplots $\left(3 \mathrm{~m}^{*} 15 \mathrm{~m}\right)$ marked by iron stakes consisting of the following treatments: shallow (SM), medium (MM), deep (DM) moldboard plowing at depths of 10,15 and $25 \mathrm{~cm}$, respectively and shallow (SD), medium (MD), deep (DD) plowing with a disk plow at depths of 10, 15 and $25 \mathrm{~cm}$, respectively (Figure 1). No-tillage (NT) was considered as control. Three replicates were laid out in randomized complete block design.

\section{Soil Sampling and Analyses}

\section{Bulk density}

The bulk density (BD) of the core sample was estimated from the ratio of dry weight to fresh volume taken with cylinder densimeter of $98.17 \mathrm{~cm}^{3}$ volume $(5 \mathrm{~cm}$ diameter and
$5 \mathrm{~cm}$ height) in all treatments from three soil cores taken by subplot from the upper $30 \mathrm{~cm}$ soil layer in $10 \mathrm{~cm}$ interval with three replications per treatment. We obtained the dry weight of the core sample after drying it in an oven at temperature of $105^{\circ} \mathrm{C}$ for 24 hours (Yoro and Godo,1990). The bulk density (BD) and the Water content can be calculated with the formula as follow:

$$
\begin{aligned}
& \text { Bulk density }(B D)\left(\frac{\mathrm{g}}{\mathrm{cm}^{3}}\right)=\frac{\text { weight of oven dried soil sample at } 105) C}{\text { total volume of fresh soil sample }} \\
& \begin{array}{c}
\text { Moisture content }(\theta)(\mathrm{cm} / \mathrm{cm}) \\
=\frac{\text { weight fresh soil sample }- \text { weight of oven dried soil sample }}{\text { weight of oven dried soil sample }}
\end{array}
\end{aligned}
$$

A total of 63 disturbed soil samples were collected at 0-0.3 $\mathrm{m}$ depth to determine the soil textural characteristics. Three textural fractions according to the USDA standards, i.e., clay $(0-2 \mu \mathrm{m})$, loam $(2-50 \mu \mathrm{m})$ and sand $(50-2000 \mu \mathrm{m})$, were used in the study to characterize the soil.

\section{The Beerkan Infiltration Method}

A simplified method based on a Beerkan infiltration run to determine the saturated soil hydraulic conductivity by only a transient infiltration process was developed.

The Beerkan method used in this study is a simple threedimensional infiltration test under positive head conditions, using a cylinder having an inner diameter of $0.30 \mathrm{~m}$. In the field, a BEST infiltration test was carried out at each sampling point $(\mathrm{N}=21)$ in April 2018. The procedure was carried out in consecutive steps as follows. The surface vegetation was removed over an area slightly larger than the cylinder diameter, while the roots remained in situ (Figure 2). Then, the cylinder is positioned at the soil surface and inserted to a depth of about $1 \mathrm{~cm}$ to avoid lateral loss of the pouded water at the soil surface. A fixed volume of water $(250 \mathrm{ml})$ was poured into the cylinder at time zero, and the time required for infiltration of the known volume of water was measured. As soon as the first volume had completely infiltrated, another equal volume of water was added to the cylinder and the time for this volume to infiltrate (cumulative time) was recorded. The procedure was repeated until the test reached nearly steady-state conditions, three identical consecutive infiltration times. In this way, each cumulative infiltration was treated using the three BEST methods (Slope, Intercept and Steady- state), which were developed respectively by

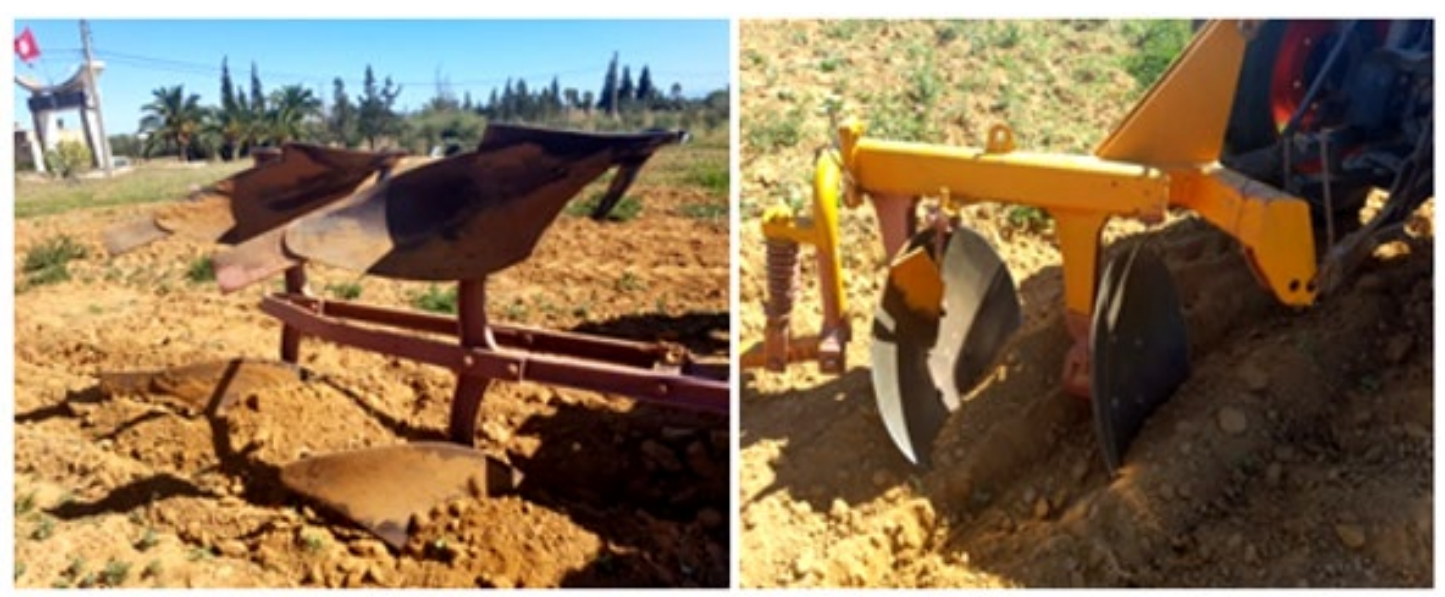

Figure 1. Various tillage implements: Tillage with moldboard plow tillage with disc plow 


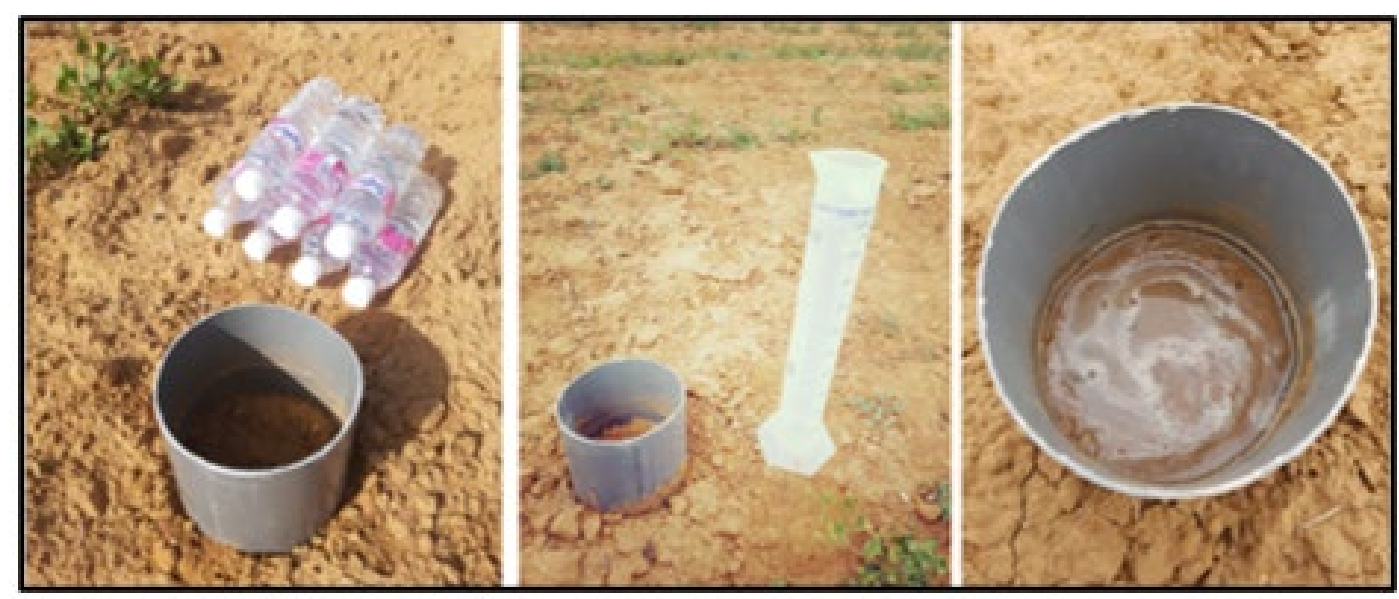

Figure 2. Beerkan infiltration. Known volumes of water prepared in the bottles are successively poured through the ring and time is measured

Table 2. Soil bulk density (BD) under tillage treatments. Within columns, letters denote statistical significance at $\mathrm{p}<0.05$ for the compari son of tillage treatments for each soil layer separately (Standard deviations are indicated in parentheses

\begin{tabular}{|c|c|c|c|c|c|c|c|c|}
\hline & $\begin{array}{c}\text { Depths } \\
\text { (cm) }\end{array}$ & NT & SD & MD & DD & SM & MM & DM \\
\hline \multirow{3}{*}{$\begin{array}{l}\text { Soil bulk } \\
\text { densities }\end{array}$} & 0.10 & $1.76 \mathrm{a} \pm(0.05)$ & 1.68 bc $\pm(0.09)$ & $1.64 \mathrm{bc} \pm(0.06)$ & $1.60 \mathrm{c} \pm(0.05)$ & $1.69 \mathrm{ab} \pm(0.05)$ & $1.66 \mathrm{bc} \pm(0.08)$ & $1.65 \mathrm{bc} \pm(0.03)$ \\
\hline & $10-20$ & $1.86 \mathrm{a} \pm(0.08)$ & $1.66 \mathrm{~b} \pm(0.06)$ & $1.63 \mathrm{bc} \pm(0.06)$ & $1.56 \mathrm{c} \pm(0.09)$ & $1.67 \mathrm{~b} \pm(0.04)$ & $1.65 \mathrm{~b} \pm(0.09)$ & $1.63 \mathrm{bc} \pm(0.05)$ \\
\hline & $20-30$ & $1.81 \mathrm{a} \pm(0.08)$ & $1.67 \mathrm{~b} \pm(0.03)$ & $1.64 \mathrm{bc} \pm(0.03)$ & $1.59 \mathrm{c} \pm(0.07)$ & $1.70 \mathrm{bc} \pm(0.11)$ & $1.63 \mathrm{bc} \pm(0.04)$ & $1.61 \mathrm{bc} \pm(0.05)$ \\
\hline
\end{tabular}

Lassabatere et al. (2006), Yilmaz et al. (2010) and Bagarello et al. (2014). At the end of the experiment, the saturated soil is sampled to determine the saturated gravimetric water content and thus the saturated volumetric water content from the bulk density (BD) and the gravimetric water content, considering that water density is $1 \mathrm{~g} / \mathrm{cm}^{3}$.

\section{RESULTS AND DISCUSSION}

\section{Effect of Tillage on Soil Bulk Density}

Data related to soil bulk density after tillage operations are given in Table 2 . Soil bulk densities are affected by tillage practices and become lower in line with more intensive tillage. This is mainly because small air spaces are formed between soil particles (clumps) of different structures during tillage (Šarauskis et al., 2018).

Statistical analysis indicated that both the tillage treatment had a significant effect on bulk density of soil (Osunbitan et al., 2005). A comparison of soil bulk density at $10 \mathrm{~cm}, 20 \mathrm{~cm}$ and $30 \mathrm{~cm}$ depths revealed the highest density to be found in No-tillage research plots $\left(1.76 ; 1.86\right.$ and $\left.1.81 \mathrm{~g} / \mathrm{cm}^{3}\right)$ respectively, and the lowest mean value to be found using disc plow at the different tillage depth (SD; MD; DD). There was no significant $(\mathrm{p}<0.05)$ differences were found between moldboard plow and disk plow treatments when operating at the same tillage depth (i.e. SD/SM; MD/MM; DD/DM) (Alvarez et al., 2009).

In the upper soil layer $(0-10 \mathrm{~cm})$, in average bulk density increases under shallow tillage represent a densification of only $4.7 \%$ related to deep tillage density mean using disk plow and $3.5 \%$ using moldboard plow. The results are in similarity with that (Dam et al., 2005) who reported that the bulk density reduced more profoundly by conventional tillage as compared to reduced tillage.

\section{Hydraulic Conductivity Changes using BEST Methods}

Each cumulative infiltration was treated using the 3 best methods (slope; intercept and steady-state); which were developed respectively by Lassabtère et al. (2006), Yilmaz et al. (2010) and bagarello et al (2014). The hydraulic conductivity varied due to tillage practices, the result presented in Figure 3 showed significant difference $(\mathrm{p}<0.05)$ between No tillage and tillage managements (disc plow and moldboard plow) for both BEST algorithms.

In this investigation, the BEST steady was considered because according to Alagna et al. (2016) it allows a simple calculation of Ks. Saturated hydraulic conductivity (Ks) after tillage practices is presented in Figure 3, revealed that both the tillage methods significantly increased the hydraulic conductivity of soil as compared to No-tillage treatment, whereas their interactive effect was statistically nonsignificant. As regard tillage method practices, the maximum mean value of saturated hydraulic conductivity $(36 \times 10-4 \mathrm{~cm} \mathrm{~s}$ ${ }^{1} ; 31 \times 10-4 \mathrm{~cm} \mathrm{~s}^{-1}$ ) was observed in case of deep tillage with disc plow (DD) and moldboard plow (DM) respectively while the mean values for the other tillage methods were 23, 27, 29, 27 and $30 \times 10-4 \mathrm{~cm} \mathrm{~s}-1$ for NT, SM, MM, SD and MD which were statistically similar. The average Mean increase in saturated hydraulic conductivity observed was $17.4 \%,(26 / 30.4 \%)$ and (34.8/56.5\%) in the shallow (SM/SD), medium (MM/MD) and deep tillage treatments (DM/DD), respectively compared to No tillage, indicating that deep tillage (DD, DM) increases the saturated hydraulic conductivity when compared to other tillage practices. These findings are in agreement with those Ikbal et al. (2005) who reported that tillage practices increased soil hydraulic conductivity. 

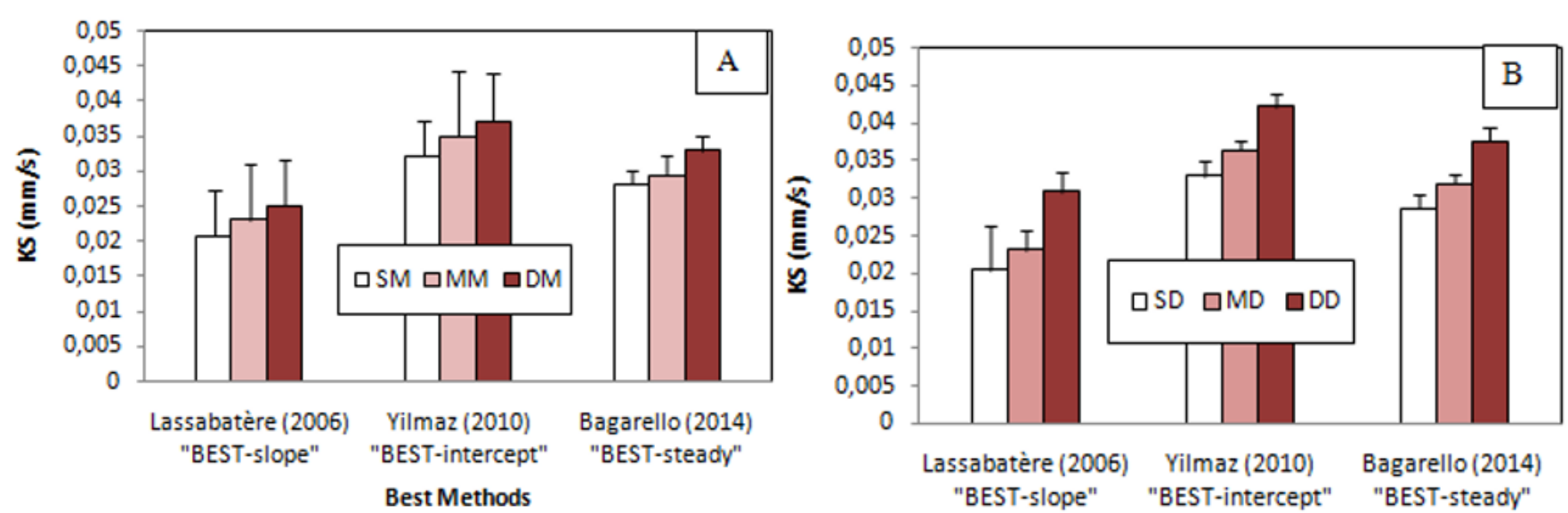

Figure 3. Soil hydraulic conductivity obtained with three BEST algorithms for the different treatments. A: Moldboard plow (SM, $\mathrm{MM}, \mathrm{DM})$; B: Disc plow (SD, MD, DD)

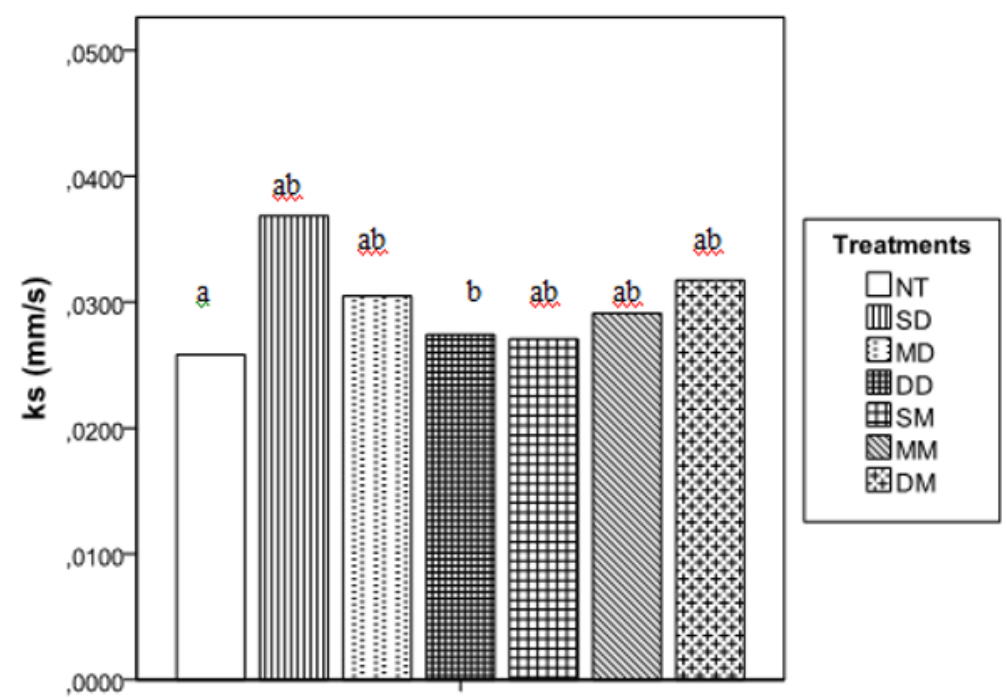

Figure 4. Mean saturated hydraulic conductivity $\left(\mathrm{mm} \mathrm{s}^{-1}\right)$ of the surface $(0-10 \mathrm{~cm})$ soil under different tillage systems at weeks after tillage obtained with the procedure by Bagarello et al. (2014)

\section{CONCLUSION}

In this study the effects of tillage practices on the soil physical properties and hydraulic conductivity were evaluated. We conclude that the effect of till with disc plow, compared to Moldboard plow, was more pronounced with changes in bulk density and hydraulic conductivity. The NT system resulted higher bulk density and lower hydraulic conductivity than disc and moldboard plow. Our results demonstrate that SD tillage is a more sustainable soil management practice than the other tillage practices with respect to soil structural stability and the higher mean value of hydraulique conductivity which can enhances better penetration of water into the plant root zone, enabling root absorption of soil moisture for better plant growth and development.

\section{ACKNOWLEDGEMENT}

This study was supported by the Research Unit 13AGRO. We are also grateful to the field staff of the Higher Agronomic Institute of Chott-Mariem for the assistance in our field work.

\section{REFERENCES}

Abrisqueta, J. M., Plana, V., Franco, J. A., \& Ruiz-Sánchez, M. C. (2006). Effect of tillage and water pressure head on the hydraulic properties of a loamy soil surface. Spanish Journal of Agricultural Research, 4(2), 180-186. https://doi.org/10.5424/sjar/2006042-190

Aiello, R., et al. (2014). An assessment of the Beerkan method for determining the hydraulic properties of a sandy loam soil. Geoderma, 235-236, 300-307. https://doi.org/10.1016/ j.geoderma.2014.07.024

Alagna, V., Bagarello, V., Di Prima, S., Giordano, G., \& Iovino, M. (2016). Testing infiltration run effects on the estimated water transmission properties of a sandy-loam soil. Geoderma, 267, 24-33. https://doi.org/10.1016/ j.geoderma.2015.12.029

Alvarez, R., \& Steinbach, H. S. (2009). A review of the effects of tillage systems on some soil physical properties, water content, nitrate availability and crops yield in the Argentine Pampas. Soil Tillage Res, 104(1), 1-15. https://doi.org/10.1016/j.still.2009.02.005 
Bagarello, V., Di Prima, S., \& Iovino, M. (2014). Comparing alternative algorithms to analyze the beerkan infiltration experiment. Soil Sci. Soc. Am. J. 78(3), 724-736. https://doi.org/10.2136/sssaj2013.06.0231

Carter, M. R., \& Ball, B. C. (1993). Soil porosity. In: M. R. Carter (Ed.), Soil sampling methods of soil analysis (pp. 581-588). Lewis Publishers.

Christopher, O. A., Olanipo, A. F., Fidelis, O. A., \& Toju, E. B. (2016). Impacts of varying tillage operations on infiltration capacity of agricultural soils. Int. J. Soil Sci., 11, 29-35. https://doi.org/10.3923/ijss.2016.29.35

Gomez, J. A., Giraldez, J. V., Pastor, M., \& Fereres, E. (1999). Effects of tillage method on soil physical properties, infiltration and yield in an olive orchard. Soil Till. Res., 52(3-4), 167-175. https://doi.org/10.1016/S01671987(99)00078-1

Hammel, J. E. (1989). Long-term tillage and crop rotation effects on bulk density and soil impedance in Northern Idaho. Soil Sci. Soc. Am. J. 53(5), 1515 -1519. https://doi.org /10.2136/sssaj1989.03615995005300050036x

Iqbal, M., Hassan, A. U., Ali, A., \& Rizwanullah, M. (2005). Residual effect of tillage and farm manure on some soil physical properties and growth of wheat (Triticum aestivum L.). International Journal of Agriculture and Biology, 7(1), 54-57.

Kameníčková, I. L., Larišováand, A., \& Stoklásková, A. (2012). The impact of different tillage treatments on hydraulic conductivity of loamy soil. Acta Universitatis Agriculturae et Silviculturae Mendelianae Brunensis, 60(5), 109-113. https://doi.org/10.11118/actaun201260050109
Lassabatère, L., Angulo-Jaramillo, R., Soria Ugalde, J. M., Cuenca, R., Braud, I., \& Haverkamp, R. (2006). Beerkan estimation of soil transfer parameters through in filtration experiments BEST. Soil Science Society of America Journal, 70(2), 521-532. https://doi.org/10.2136/sssaj2005.0026

Lindstrom, M. J., \& Onstad, C. A. (1984). Influence of tillage systems on soil physical parameters and infiltration after planting. J. Soil Water Conserv., 39(2), 149-152.

Osunbitan, J. A., Oyedele, D. J., \& Adekalu, K. O. (2005). Tillage effects on bulk density, hydraulic conductivity and strength of a loamy sand soil in southwestern Nigeria. Soil Till. Res., 82(1), 57-64. https://doi.org/10.1016/ j.still.2004.05.007

Strudley, W. M., Green, T. R., \& Ascough II, J. C. (2008). Tillage effects on soil hydraulic properties in space and time: State of the science. Soil and Tillage Research, 99(1), 4-48. https://doi.org/10.1016/j.still.2008.01.007

Unger, P. W. (1984). Tillage effects on surface soil physical conditions and sorghum emergence. Soil Sci. Soc. Am. J., 48(6), 1423-1432. https://doi.org/10.2136/sssaj1984. $03615995004800060044 \mathrm{x}$

Voorhees, W. B., \& Linstrom, M. J. (1984). Long-term effects of tillage method on soil tilth independent of wheel traffic compaction. Soil Sci. Soc. Am. J., 48(1), 152-156. https:// doi.org/10.2136/sssaj1984.03615995004800010028x

Yilmaz, D., Lassabatere, L., Angulo-Jaramillo, R., Deneele, D., \& Legret, M. (2010). Hydrodynamic characterization of basic oxygen furnace slag through an adapted BEST method. Vadose Zone J. 9(1), 107. https://doi.org/10.2136/vzj2009.0039

Yoro, G., \& Godo, G. (1990). Les méthodes de mesure de la densité apparente. Analyse de la dispersion des résultats dans un horizon donné. Cah. Orstom, sér. Pédol., XXV(4), 423-429. 